N.M. Korniichuk ${ }^{1}$, S.P. Turanska ${ }^{1}$, A.L. Petranovska ${ }^{1}$, M.V. Abramov ${ }^{1}$, P.P. Gorbyk ${ }^{1,2}$, N.Yu. Luk'yanova ${ }^{3}$, N.V. Kusyak ${ }^{4}$, V.F. Chekhun ${ }^{3}$

\title{
MAGNETICALLY SENSITIVE NANOCOMPOSITES FOR TARGETED ANTITUMOR THERAPY WITH APPLICATION OF GEMCITABINE
}

\author{
${ }^{1}$ Chuiko Institute of Surface Chemistry of National Academy of Sciences of Ukraine \\ 17 General Naumov Str., Kyiv, 03164,Ukraine, E-mail: phorbyk@ukr.net \\ ${ }^{2}$ National Technical University of Ukraine "Igor Sikorsky Kyiv Polytechnic Institute" \\ 37 Prospekt Peremohy, Kyiv, 03056, Ukraine \\ ${ }^{3}$ R.E. Kavetsky Institute of Experimental Pathology, Oncology and Radiobiology of National Academy of Sciences of Ukraine \\ 45 Vasylkivska Str., Kyiv, 03022, Ukraine \\ ${ }^{4}$ Ivan Franko Zhytomyr State University \\ 40 V. Berdychivska Str., Zhytomyr, 10008, Ukraine
}

The aim of the work is synthesis and study on the properties of polyfunctional magnetosensitive nanocomposites (NC) and target-directed magnetic fluids (MF) based on physiological solution (PS), magnetite, gemcitabine (GEM) and HER 2 antibodies $(A B)$, promising for use in targeted antitumor therapy against MDA-MB-231 aggressive tumor cells of triple-negative human breast cancer $(B C)$ with high proliferative and metastatic activity.

The specific surface area $\left(S_{s p}\right)$ of samples was determined by the method of thermal desorption of nitrogen using a device KELVIN 1042 of "COSTECH Instruments". The size of nanoparticles (NP) has been estimated by the formula $D_{B E T}=6 /\left(\rho S_{B E T}\right)$, where $\rho$ is the density of $N C$ particle, $S_{B E T}$ is the value of the specific surface area calculated by the polymolecular adsorption theory of Brunauer, Emmett and Teller (BET). The surface condition of nanodispersed samples was studied by IR spectroscopy ("Perkin Elmer" Fourier spectrometer, a model 1720X). To calculate the concentration of hydroxyl groups on the surface of nanostructures, the method of differential thermal analysis was used in combination with differential thermogravimetric analysis. The thermograms were recorded using a derivatograph Q-1500D of MOM firm (Hungary) in the temperature range of $20-1000{ }^{\circ} \mathrm{C}$ at a heating rate of $10 \mathrm{deg} / \mathrm{min}$. X-ray phase analysis of nanostructures was performed using a diffractometer DRON-4-07 (CuK $\mathrm{K}_{\alpha}$ radiation with a nickel filter in a reflected beam, the Bragg-Brentano focusing). The size and shape of NP were determined by electron microscopy (a transmission electron microscope (TEM) JEM-2100F (Japan)). The hysteresis loops of the magnetic moment of the samples were measured using a laboratory vibration magnetometer of Foner type at room temperature. Measurement of optical density, absorption spectra and GEM concentration in solutions was performed by spectrophotometric analysis (Spectrometer Lambda 35 UV/Vis Perkin Elmer Instruments). The amount of adsorbed substance on the surface of magnetite was determined using a spectrophotometer at $\lambda=268 \mathrm{~nm}$ from a calibration graph. The thickness of the adsorbed layer of GEM in the composition of $\mathrm{Fe}_{3} \mathrm{O}_{4} @ G E M \mathrm{NC}_{\text {was }}$ determined by magnetic granulometry. To study the direct cytotoxic/cytostatic effect of a series of experimental samples of $\mathrm{MF}$ based on PS, $\mathrm{Fe}_{3} \mathrm{O}_{4} \mathrm{NP}, \mathrm{GEM}$, HER2 AB, as well as MF components in mono- or complex use, onto $M D A-M B-231$ cells in vitro, $I C_{50}$ index was determined.

$M F$ were synthesized on the basis of single-domain $\mathrm{Fe}_{3} \mathrm{O}_{4}$ and $\mathrm{PS}$, stabilized with sodium oleate (Ol.Na) and polyethylene glycol (PEG), containing GEM and HER2 ( $\left.\mathrm{Fe}_{3} \mathrm{O}_{4} @ G E M / O l . N a / P E G / H E R 2+P S\right)$. The cytotoxic/cytostatic activity of $M F$ against $M D A-M B-231$ cells was studied. It was found that as a result of application of synthesized $\mathrm{MF}$ composed of $\mathrm{Fe}_{3} \mathrm{O}_{4} @ G E M / O l . \mathrm{Na} / \mathrm{PEG} / \mathrm{HER} 2+\mathrm{PS}$ at the concentration of magnetite of $0.05 \mathrm{mg} / \mathrm{mL}, G E M-0.004 \mathrm{mg} / \mathrm{mL}$ and HER2 $\mathrm{AB}-0.013 \mu \mathrm{g} / \mathrm{mL}$, a synergistic effect arose, with reduction of the amount of viable $\mathrm{BC}$ cells to $51 \%$. It has been proved that when using $\mathrm{MF}$ based on targeted $\mathrm{Fe}_{3} \mathrm{O}_{4} / G E M / H E R 2$ complex, the increased antitumor efficacy is observed compared to traditional use of the drug GEM, with a significant reduction (by four times) of its dose. The high cytotoxic/cytostatic activity of $\mathrm{Fe}_{3} \mathrm{O}_{4} / \mathrm{GEM}_{\mathrm{H}} / \mathrm{HER} 2$ complexes is explained by the fact that endogenous iron metabolism disorders play a significant role in the mechanisms of realization of the apoptotic program under the influence of nanocomposite. Thus, when the nanocomposite system contains $\mathrm{Fe}_{3} \mathrm{O}_{4} / G E M / H E R 2$ complexes in MDA-MB-231 cells, a significant increase is observed in the level of "free iron", which favours formation of reactive oxygen species and causes oxidative stress (Fenton reaction). The consequences of oxidative stress are induction of apoptosis, enhancement of lipid peroxidation processes, as well as structural and functional rearrangement of biological membranes. The prospects 
have been shown of further studies of $\mathrm{Fe}_{3} \mathrm{O}_{4} @ G E M / O l . N a / P E G / H E R 2+P S M F$ in order to create on their basis a magnetically carried remedy for use in targeted antitumor therapy.

Keywords: gemcitabine, nanosized single-domain magnetite, core-shell nanocomposites, magnetic fluids, HER2 antibody, targeted antitumor therapy

\section{INTRODUCTION}

One of the main problems of modern antitumor therapy with gemcitabine (GEM) is its toxic effects on the human body and the occurrence of severe adverse reactions in patients [1-4]. Therefore, a generally accepted alternative to traditional GEM chemotherapy has been the use of targeted delivery methods [5-11], which allows us to create a therapeutic dose of the drug in the disease locus, to carry out therapy at a much lower total dose and minimize side effects. Among the variety of modern methods of targeted drug delivery and local therapy of diseases at the level of organs, cells and genes, the most developed at this time are methods using magnetically sensitive nanostructures conjugated with antitumor drugs of different mechanism of action.

To date, a concept has been substantiated of chemical construction of magnetosensitive nanocomposites (NC) with multilevel hierarchical nanoarchitecture, characterized by the functions of "nanoclinics" and medicobiological nanorobots [12-17]: recognition of microbiological objects in biological media; targeted delivery of drugs to specific cells and organs, and deposition; complex local chemo-, immuno-, neutron-capture, hyperthermic, photodynamic therapy and magnetic resonance imaging in real time, detoxification of the body by adsorption of cell decomposition residues, viral particles, heavy metal ions, etc. and their removal with the aid of magnetic field [18-24]. The urgency of the topic is due to its focus on the creation of the latest medical theranostic remedies for targeted delivery of drugs with different mechanisms of action, and local complex therapy, primarily for the needs of oncology.

For the manufacture of magnetically sensitive multifunctional $\mathrm{NC}$, a significant interest of researchers is drawn to nanostructures of core-shell type based on single-domain magnetite $\left(\mathrm{Fe}_{3} \mathrm{O}_{4}\right)$, which are characterized by a unique set of physical, chemical and biological properties, the capability to create magnetic fluids (MF) on their basis, containing oncological remedies with various functional purpose and mechanisms of action [25, 26].

In recent years, there has been a significant increase in the use of natural mechanisms of endocytosis and nanostructures of various types to deliver drugs to tumors, involving ligands such as hormones, vitamins and growth factors against tumor-associated receptors that are overexpressed on tumor cell surfaces, with limited distribution in normal tissues $[9,11,27]$. At present, magnetically sensitive and nonmagnetic conjugates are actively being developed by the methods of modern nanotechnology to deliver GEM in a targeted manner to malignant cells, which will allow to reduce its systemic toxicity. The advantage of the use of drug conjugation on the surface of nanoparticles to deliver drugs in vivo is a slow release of the drug, which potentially provides a longer presence of the drug in the bloodstream at the required level. A positive result of the use of hyperthermia in combination with prolonged drug release may be an improvement in the patient's condition and a decrease in the frequency of drug reception.

Despite a large number of successful studies on the use of magnetic nanoparticles as a theranostic material, as well as repeated successful results in small animal models, they still do not meet clinical needs. However, upon reaching high drug capacity, increased specificity and affinity for tumor cells, a combination of imaging and multimodal local therapy, magnetic nanoparticles may become convenient for clinical use in the near future and significantly affect the effectiveness of cancer treatment.

We note that a review of scientific publications is contained in [28] on the synthesis, study of properties of magnetosensitive $\mathrm{NC}$ based on GEM, promising for use in the method of targeted delivery, and their applications in medicine, in particular antitumor therapy.

The aim of this work is to synthesize and study the properties of magnetically sensitive polyfunctional $\mathrm{NC}$ and target-directed magnetic fluids based on magnetite and GEM, promising for use in targeted antitumor therapy against 
MDA-MB-231 cells of aggressive tumor with high proliferative and metastatic activity, three times negative human breast cancer (BC).

\section{EXPERIMENTAL PART AND DISCUSSION}

Research methods and results. Gemcitabine ((2-deoxy-2',2)difluorocytidine monochloride) is a cytotoxic drug, an antimetabolite from the group of pyrimidine antagonists, that has been chosen as the drug of chemotherapeutic mechanism of action. GEM belongs to the List of basic medicines of the World Health Organization and the most effective and safe drugs needed in the health care system. It is characterized by considerable antitumor activity in the treatment of solid tumors (non-small cell lung cancer, pancreatic, bladder, breast, ovarian cancer), satisfactory tolerability and the possibility of successful combination with other antitumor drugs. It is used for treatment of cholangiocarcinoma and other types of bile duct cancer. Currently, the possibility is being actively studied $[5-11,28]$ to use GEM in the composition of magnetosensitive NC to create polyfunctional antitumor drugs for targeted delivery and local therapy, e.g. breast cancer, hepatocellular carcinoma, osteosarcoma, etc.

The antibody (AB) HER2 (Neu, ErbB-2, $\mathrm{CD} 340$ ) is a membrane protein, tyrosine proteinkinase of EGFR/ErbB epidermal growth factor receptor family, which is encoded by ERBB2 human gene, it has been chosen as a drug of immunotherapeutic mechanism of action. HER2 gene amplification plays an important role in the pathogenesis and progression of certain aggressive types of cancer [29-31]. HER2 is an important biomarker and therapeutic target of the disease, associated with tumor aggressiveness and unfavorable prognosis. HER2 $\mathrm{AB}$ is considered to be an optimal for the treatment of diseases such as human $\mathrm{BC}$, in particular, in the presence of metastases. Therefore, for in vitro studies, we chose HER2 AB in combination with GC in composition of MF based on magnetite.

To test the antitumor activity of the synthesized MF in vitro, in this work we chose MDA-MB-231 cells of the aggressive tumor with high proliferative and metastatic activity, three times negative human BC.

Samples of magnetically sensitive nanostructures (ensembles of $\mathrm{Fe}_{3} \mathrm{O}_{4}$ nanoparticles (NP) and $\mathrm{Fe}_{3} \mathrm{O}_{4} @$ GEM NC) and MF stabilized with sodium oleate (Ol.Na) and polyethylene glycol (PEG) were synthesized for research.

The synthesis of nanodispersed magnetite was carried out according to the technique [10] by coprecipitation of iron salts by the reaction:

$\mathrm{Fe}^{+2}+2 \mathrm{Fe}^{+3}+8 \mathrm{NH}_{4} \mathrm{OH} \rightarrow \mathrm{Fe}_{3} \mathrm{O}_{4}+4 \mathrm{H}_{2} \mathrm{O}+8 \mathrm{NH}_{4}^{+}$.

The synthesized ensembles of $\mathrm{Fe}_{3} \mathrm{O}_{4}$ NP were characterized by sizes of $3-23 \mathrm{~nm}$. The average size $\left(d_{0}\right)$ of NP depended on the synthesis conditions and was $6-13 \mathrm{~nm}$, and the size distribution could be controlled technologically.

The specific surface area $\left(S_{s p}\right)$ of the samples was determined by the method of thermal desorption of nitrogen on a device KELVIN 1042 of "COSTECH Instruments" firm. The size of NP has been estimated by the formula $D_{\mathrm{BET}}=6 /\left(\rho S_{\mathrm{BET}}\right)$, where $\rho$ is the density of NC particle, $S_{\mathrm{BET}}$ is the value of the specific surface area calculated by the polymolecular adsorption theory of Brunauer, Emmett and Teller (BET). The specific surface area $\left(S_{s p}\right)$ of synthesized magnetite was $S_{s p}=90-180 \mathrm{~m}^{2} / \mathrm{g}$, dependent on the average particle size, in this work we used samples with $S_{s p}=110 \pm 1 \% \mathrm{~m}^{2} / \mathrm{g}$.

The surface condition of nanodispersed samples was studied by IR spectroscopy ("Perkin Elmer" Fourier spectrometer, a 1720X model). $\mathrm{OH}$ functional groups were revealed by the study on IR spectra of magnetite surface. To calculate the concentration of hydroxyl groups on the surface of nanostructures, the method of differential thermal analysis was used in combination with differential thermogravimetric analysis. Thermograms were recorded using a Q-1500D derivatograph of MOM firm (Hungary) in the temperature range of $20-1000{ }^{\circ} \mathrm{C}$ at a heating rate of $10 \mathrm{deg} / \mathrm{min}$. It has been found that the concentration of $\mathrm{OH}$ functional groups on the surface of magnetite is $2.4 \mathrm{mmol} / \mathrm{g}$.

X-ray phase analysis of nanostructures was performed using a diffractometer DRON-4-07 $\left(\mathrm{Cu} K_{\alpha}\right.$ radiation with a nickel filter in a reflected beam, the Bragg-Brentano focusing). The size of the crystallites was determined from the width of the corresponding most intense line according to the Scherrer equation. The value of the average diameter of $\mathrm{Fe}_{3} \mathrm{O}_{4} \mathrm{NP}$, calculated from the results of investigation of X-ray diffraction patterns according to the Scherrer formula, $D_{X R D}$ was $10.5 \mathrm{~nm}$. 
To study the morphology and size distribution of NP, their dispersions in water were used. The size and shape of NP were determined by electron microscopy (a transmission electron microscope (TEM) JEM2100F (Japan)). $\mathrm{Fe}_{3} \mathrm{O}_{4} \mathrm{NP}$ in ensemble were characterized by spheroidal shape, their average size was $\sim 10.8 \mathrm{~nm}$.

The hysteresis loops of the magnetic moment of the samples were measured using a laboratory vibration magnetometer of Foner type at room temperature. Description of the installation and the measurement technique are set out in [32]. Demagnetized nanoparticles were distributed in a paraffin matrix with a volume concentration of $\sim 0.05$ to prevent interaction. For comparison, we used materials with a known value of the specific saturation magnetization $\left(\sigma_{s}\right)$ : a tested sample of nickel and $\mathrm{Fe}_{3} \mathrm{O}_{4} \mathrm{NP}$ $(98 \%)$ manufactured by "Nanostructured \& Amorphous Materials Inc.", USA. The error in measuring $\sigma_{s}$ did not exceed $2.5 \%$ in relation to the reference sample. Table 1 shows the magnetic characteristics of the synthesized ensemble of magnetite nanoparticles.

Table 1. Magnetic characteristics of the ensemble of magnetite nanoparticles

\begin{tabular}{|c|c|c|c|c|c|}
\hline Sample & $\boldsymbol{H}_{c}, \mathbf{O e}$ & $\sigma_{s}, \mathrm{emu} / \mathrm{g}$ & $\sigma_{r}, \mathrm{emu} / \mathrm{g}$ & $\sigma_{r} / \sigma_{s}$ & $\alpha_{\mathrm{Fe} 3 \mathrm{O} 4^{\text {calc }}, \%} \%$ \\
\hline $\mathrm{Fe}_{3} \mathrm{O}_{4}$ & 41 & 57.7 & 10.4 & 0.18 & 100 \\
\hline
\end{tabular}

$H_{c}$, Oe is the coercive force; $\sigma_{s}, \mathrm{emu} / \mathrm{g}$ is the specific saturation magnetization of $\mathrm{NC} ; \sigma_{r}$, emu/g is the residual specific magnetization of $\mathrm{NC} ; \sigma_{r} / \sigma_{s}$ is the relative residual magnetization; $\alpha_{\mathrm{Fe} 304}{ }^{\text {calc }}$ is the calculated mass concentration of $\mathrm{Fe}_{3} \mathrm{O}_{4}$ in $\mathrm{NC}, \%$

Measuring of optical density, absorption spectra and GEM concentration in solutions was performed by spectrophotometric analysis (a spectrometer Lambda $35 \mathrm{UV} /$ Vis Perkin Elmer Instruments).

The adsorption capacity of samples $A(\mathrm{mg} / \mathrm{g})$ has been calculated by the formula: $A=\left(C_{0}-C_{e q}\right) \cdot V / m$, where $C_{0}$ and $C_{e q}$ are the concentration of the initial solution and the solution after adsorption $(\mathrm{mg} / \mathrm{L}), V$ is the volume of the solution $(L), m$ is the mass of the sorbent $(g)$. Adsorption isotherms were constructed on the basis of experimental results. The coefficients of distribution $E(\mathrm{~mL} / \mathrm{g})$ of GEM between the surface of nanostructures and the solution, the extraction extent $R(\%)$ were determined by the formulas: $E=A / C_{e q}$, $R=\left(1-C_{e q} / C_{0}\right) \cdot 100 \%$, respectively.
Gemcitabine TEVA (Pharmachemie BV, the Netherlands) was used for research in this work. Adsorption of GEM on the surface of magnetite $\mathrm{Fe}_{3} \mathrm{O}_{4}$ was performed in physiological solution in the concentration range $C_{0}=0.02-0.67 \mathrm{mg} / \mathrm{mL}$ $(m=0.03 \mathrm{~g}, V=5 \mathrm{~mL}, \mathrm{pH}=3.0)$ for $2 \mathrm{~h}$ in a dynamic mode at room temperature. The level of $\mathrm{pH}$ of the medium of GEM solution in $0.9 \%$ $\mathrm{NaCl}$ was set by $0.1 \mathrm{~N} \mathrm{HCl}$. The amount of adsorbed substance on the surface of magnetite was determined using a spectrophotometer at $\lambda=268 \mathrm{~nm}$ from a calibration graph.

The experimental values of adsorption capacity $A$ of magnetite surface were $\sim 37.2 \mathrm{mg} / \mathrm{g}$, extraction extent $R-33.13 \%$, distribution coefficient $E=82.58 \mathrm{~mL} / \mathrm{g}$.

The magnetic characteristics of magnetite with adsorbed GEM $\left(\mathrm{Fe}_{3} \mathrm{O}_{4} @\right.$ GEM NC) are given in Table 2.

Table 2. Magnetic characteristics of $\mathrm{Fe}_{3} \mathrm{O}_{4} @$ GEM NC

\begin{tabular}{|c|c|c|c|c|c|}
\hline Sample & $H_{c}$, Oe & $\sigma_{s}, \mathrm{emu} / \mathrm{g}$ & $\sigma_{r}, \mathrm{emu} / \mathrm{g}$ & $\sigma_{r} / \sigma_{s}$ & $\alpha_{\mathrm{Fe} 3 \mathrm{O} 4^{c a l c}, \%} \%$ \\
\hline $\mathrm{Fe}_{3} \mathrm{O}_{4} @ \mathrm{GEM}$ & 44 & 39.0 & 6.07 & 0.15 & 68 \\
\hline
\end{tabular}

Using the method of magnetic granulometry and assuming that the thickness of GEM layers depends a little on the diameter of $\mathrm{Fe}_{3} \mathrm{O}_{4} \mathrm{NP}$, we have estimated the average value of the thickness of the adsorbed GEM layer in the composition of $\mathrm{Fe}_{3} \mathrm{O}_{4} @$ GEM NC, which is $2.4 \pm 0.1 \mathrm{~nm}$.

Synthesis and properties of magnetic fluids. MF were synthesized based on magnetite and 
physiological solution (PS), stabilized with Ol.Na and PEG, containing GEM $\left(\mathrm{Fe}_{3} \mathrm{O}_{4} @\right.$ GEM/Ol.Na/PEG+PS).

As the dispersed phase of MF, nanosized magnetite in the single-domain state was used at the concentration of $14 \mathrm{mg} / \mathrm{mL}$ (for comparison), or $\mathrm{Fe}_{3} \mathrm{O}_{4} @$ GEM NC based on it.

To prevent aggregation, $\mathrm{Fe}_{3} \mathrm{O}_{4}$ and $\mathrm{NC}$ nanoparticles were stabilized with sodium oleate $\left(\mathrm{C}_{8} \mathrm{H}_{17} \mathrm{CH}=\mathrm{CH}\left(\mathrm{CH}_{2}\right)_{7} \mathrm{CO}-\mathrm{O}-\mathrm{Na}, \quad\right.$ dynamic mode, $1 \mathrm{~h}$ ), and polyethylene glycol (PEG-2000).

To stabilize the surface of NP and NC in the composition of MF, the mass of sodium oleate $m_{\mathrm{Ol} . \mathrm{Na}}$ was calculated taking into account the concentration of reactive hydroxyl groups on the surface of magnetite. The calculation was performed according to the formula: $m_{\mathrm{Ol} . \mathrm{Na}}=B \cdot M \cdot m$, where $B$ is the concentration of hydroxyl groups $(2.2 \mathrm{mmol} / \mathrm{g})$ on the surface of starting nanosized magnetite, $M$ is the molecular mass of sodium oleate (304 Da), $m$ is the mass of $\mathrm{Fe}_{3} \mathrm{O}_{4}$ or $\mathrm{NC}$.

It is known that PEG prevents the adsorption interactions of fluid components with protein molecules [33], which is important in medical applications of MF. Additional modification with PEG-2000 was carried out in a dynamic mode using a shaker, the amount of polymer was $10-15 \%$ by weight of the sample of $\mathrm{Fe}_{3} \mathrm{O}_{4} \mathrm{NP}$, or $\mathrm{NC}[34,35]$. The double stabilizing layer of NC (Ol.Na@PEG) was considered to be continuous with thickness $\approx 3 \mathrm{~nm}$ in water and $\mathrm{PS}$, and $\approx 1 \mathrm{~nm}$ in dry residues [35].

Putting of HER 2 AB into the composition of $\mathrm{Fe}_{3} \mathrm{O}_{4} @$ GEM/Ol.Na/PEG+PS MF and obtaining of $\mathrm{Fe}_{3} \mathrm{O}_{4} @$ GEM/O1.Na/PEG/HER2 AB+PS MF was performed in a dynamic mode using a shaker.

To obtain optimal experimental MF based on magnetite, we used compositions with the following parameters: concentration of $\mathrm{Fe}_{3} \mathrm{O}_{4}-$ $14 \mathrm{mg} / \mathrm{mL}$, particle size of $\mathrm{Fe}_{3} \mathrm{O}_{4}-4-22 \mathrm{~nm}$, average particle size of $\mathrm{Fe}_{3} \mathrm{O}_{4}-10.8 \mathrm{~nm}$; average particle size of $\mathrm{Fe}_{3} \mathrm{O}_{4}$ stabilized with sodium oleate - $16.8 \mathrm{~nm}$; saturation magnetization $M_{\infty}=14.1 \pm 2.5 \%$ Gs, hypsometric height $25 \pm 10 \% \mathrm{~cm}$, viscosity $\eta=1.14 \pm 3 \% \mathrm{mPa} \cdot \mathrm{s}$, density $\rho_{M F}=1.14 \pm 1.0 \% \quad \mathrm{~g} / \mathrm{cm}^{3}$, the concentration of GEM was $1.25 \mathrm{mg} / \mathrm{mL}$, HER2 $\mathrm{AB}-3.75 \mu \mathrm{g} / \mathrm{mL}$.

The concentration of GEM and HER $2 \mathrm{AB}$ in such MF is determined by the therapeutic need. In the starting MF, the concentration of GEM and HER2 $\mathrm{AB}$ has been $1.25 \mathrm{mg} / \mathrm{mL}$ and $3.75 \mu \mathrm{g} / \mathrm{mL}$, respectively, which allows us to provide the required doses of the drug in the test samples by diluting the starting MR. In addition, this fluid is characterized by satisfactory rheological properties and sedimentation stability.

We note that the conditions used in these studies for the synthesis of magnetite, adsorption immobilization of GEM on the surface of nanosized $\mathrm{Fe}_{3} \mathrm{O}_{4}$, production of $\mathrm{MF}$, as well as the magnetic properties of the research samples are described in more detail in $[9,11,25,26]$.

Investigation of the influence of experimental samples on the viability of $M D A-M B-231$ cells of human $B C$ in vitro. To study the direct cytotoxic/cytostatic effect of a series of experimental samples of MF based on PS, $\mathrm{Fe}_{3} \mathrm{O}_{4}$ NP, GEM, $\mathrm{Fe}_{3} \mathrm{O}_{4} @$ GEM NC, HER2 $\mathrm{AB}$, in mono- or complex application onto MDA-MB-231 cells in vitro, $\mathrm{IC}_{50}$ index was determined.

The description of the used samples, materials, devices and methods is given below.

Samples

1. MF: $\mathrm{Fe}_{3} \mathrm{O}_{4} @ \mathrm{Ol} . \mathrm{Na} / \mathrm{PEG}+\mathrm{PS}$ (control 1),

2. Gemcitabine + PS (control 2),

3. HER2 AB + PS (control 3),

4. $\mathrm{MF}+\mathrm{GEM}: \mathrm{Fe}_{3} \mathrm{O}_{4} @$ GEM/Ol.Na/PEG + PS,

5. $\mathrm{MF}+\mathrm{AB}: \mathrm{Fe}_{3} \mathrm{O}_{4} @ \mathrm{Ol} . \mathrm{Na} / \mathrm{PEG}+\mathrm{PS}+\mathrm{HER} 2$,

6. $\mathrm{MF}+\mathrm{GEM}+\mathrm{AB}: \mathrm{Fe}_{3} \mathrm{O}_{4} @ \mathrm{GEM} / \mathrm{Ol}$.Na/PEG

+ PS + HER2,

7. GEM + HER 2 + PS (control 4),

8. PS (control 5).

For all the corresponding systems, the concentration of $\mathrm{Fe}_{3} \mathrm{O}_{4}$ was $C_{\mathrm{Fe} 304}=3 \mathrm{mg} / \mathrm{mL}$, the concentration of GEM $C_{\mathrm{GEM}}=0.25 \mathrm{mg} / \mathrm{mL}$, antibodies $-C_{\mathrm{HER} 2 \mathrm{AB}}=0.75 \mu \mathrm{g} / \mathrm{mL}$.

\section{Materials}

Medium: DMEM High glucose (Biowest, France, catalog No. L0102-500).

Serum: fetal calf serum (FCS) (Biowest, France, catalog No. S181B-500).

Solutions: Versene solution (BioTestLaboratory, Ukraine), phosphate-saline buffer (Sigma, USA, cat. No. D1408), physiological solution (Lekhim, Ukraine, 71033007 series), ethyl alcohol (Ukrspirt, Ukraine).

Dyes: crystalline violet (Sigma, USA, cat. No. C6158).

Other materials: plastic ware for cell culture (TPP, Italy), 96-well plates for cell culture (SPL, Korea). 
Devices

$\mathrm{CO}_{2}$ incubator (Heal Force, China), an inverted microscope Axiovert 25 (Carl Zeiss, Germany), a Goryaev camera (Pharmmedtech, Ukraine), a mini-shaker PSU-2T (BioSan, Latvia), a multiwell spectrophotometer (Labsystems Multiskan PLUS, Finland), automatic pipettes up to $20 \mu \mathrm{L}$ (Eppendorf $\mathrm{AG}$, Germany), $200 \mu \mathrm{L}$ (Thermo Fisher Scientific Oy, Finland) and $1000 \mu \mathrm{L}$ (Eppendorf AG, Germany).

\section{Methods}

The tested cells were cultured in complete DMEM medium with $10 \%$ FCS and $40 \mu \mathrm{g} / \mathrm{mL}$ of gentamicin in a plastic ware in humidified atmosphere at $5 \% \mathrm{CO}_{2}$ and $37^{\circ} \mathrm{C}$. Changing of the medium and resowing of cells were performed according to standard technique [36]. The cells in the exponential phase of growth were used for experiments. In 24-48 h after the last resowing, the cells were planted out for cultivation at a concentration of $1-1.5 \times 10^{4}$ cells/well of a 96-well plate. In $24 \mathrm{~h}$, different amounts of experimental substances were added to the respective wells according to the study scheme. Syringe filters were used when making the solutions. The cells were incubated for another $48 \mathrm{~h}$, and the cytotoxic effect of each experimental substance was determined.

The viability of cells in the experiment was evaluated by colorimetric method, staining the cells with crystalline violet. Adhesive cells are separated from the substrate after death. This property is used to determine the number of living cells after treatment with test agents. One way to detect attached (living) cells is to stain them with a crystalline violet dye that binds to proteins and DNA. The results were evaluated using a multi-well spectrophotometer (wavelength $540 \mathrm{~nm}$ ). The percentage of viable cells $\left(I_{\mathrm{R}}\right)$ was calculated by the formula:

$I_{\mathrm{R}}=\left(A_{540} \quad\right.$ (experiment $) / A_{540}($ control $\left.)\right) \times 100 \%$, where $A_{540}$ is absorption (the value proportional to cell concentration) at wavelength of $540 \mathrm{~nm}$.

Cytotoxic and antiproliferative activity was determined using the index "inhibitory concentration 50" ( $\mathrm{IC}_{50}$ - the concentration of the test substance at which $50 \%$ of cells die), which was calculated using Excel program. Table 3 shows the results of the study of the effect of concentrations of the studied preparations when used in mono-regime and their combinations on the viability of MDA-MB-231 cells.

Table 3. Influence of concentrations of the studied preparations in mono-regime and their combinations on the viability of MDA-MB-231 cells

\begin{tabular}{|c|c|c|c|c|c|c|c|c|c|c|}
\hline & $\frac{\text { Sample }}{\text { ncentrat }}$ & & MF & GEM & HER2 & $\begin{array}{l}\text { MF+ } \\
\text { GEM }\end{array}$ & $\begin{array}{c}\text { MF+ } \\
\text { HER2 }\end{array}$ & $\begin{array}{c}\text { MF+ } \\
\text { GEM+ } \\
\text { HER2 }\end{array}$ & $\begin{array}{c}\text { GEM+ } \\
\text { HER2 }\end{array}$ & PS \\
\hline $\begin{array}{c}\text { MF*, } \\
\text { mg/mL }\end{array}$ & $\begin{array}{c}\text { GEM, } \\
\mathrm{mg} / \mathrm{mL}\end{array}$ & $\begin{array}{l}\text { HER2, } \\
\mu \mathrm{g} / \mathrm{mL}\end{array}$ & \multicolumn{8}{|c|}{ Amount of living cells, $\% * *$} \\
\hline 1.5 & 0.125 & 0.38 & - *** & $\begin{array}{c}38.0 \pm \\
1.7\end{array}$ & $\begin{array}{c}89.7 \pm \\
1.9\end{array}$ & $-* * *$ & - *** & -*** & $\begin{array}{c}36.5 \pm \\
1.8\end{array}$ & $\begin{array}{c}96.0 \pm \\
3.1\end{array}$ \\
\hline 0.75 & 0.063 & 0.19 & $-* * *$ & $\begin{array}{c}35.0 \pm \\
2.2\end{array}$ & $88.7 \pm 2.9$ & - *** & _*** & -*** & $\begin{array}{c}35.0 \pm \\
2.4\end{array}$ & $\begin{array}{c}89.7 \pm \\
6.6\end{array}$ \\
\hline 0.38 & 0.031 & 0.1 & - *** & $\begin{array}{c}38.6 \pm \\
1.6\end{array}$ & $98.8 \pm 4.6$ & - *** & $-* * *$ & $-* * *$ & $\begin{array}{c}36.9 \pm \\
4.1\end{array}$ & $\begin{array}{c}97.3 \pm \\
1.3\end{array}$ \\
\hline 0.19 & 0.016 & 0.05 & -*** & $\begin{array}{c}48.5 \pm \\
2.2\end{array}$ & $98.4 \pm 5.9$ & -*** & $-* * *$ & $-* * *$ & $\begin{array}{c}46.4 \pm \\
3.2\end{array}$ & $\begin{array}{c}94.5 \pm \\
1.9\end{array}$ \\
\hline 0.1 & 0.008 & 0.025 & $\begin{array}{c}91.3 \pm \\
6.6\end{array}$ & $\begin{array}{c}72.4 \pm \\
1.9\end{array}$ & $\begin{array}{c}100.0 \pm \\
2.3\end{array}$ & $\begin{array}{c}70.7 \pm \\
6.7\end{array}$ & $\begin{array}{c}85.9 \pm \\
4.3\end{array}$ & $\begin{array}{c}55.0 \pm \\
5.7\end{array}$ & $\begin{array}{c}63.9 \pm \\
2.5\end{array}$ & $\begin{array}{c}90.9 \pm \\
6.2\end{array}$ \\
\hline 0.05 & 0.004 & 0.013 & $\begin{array}{c}90.1 \pm \\
7.0\end{array}$ & $\begin{array}{c}74.3 \pm \\
2.4\end{array}$ & $\begin{array}{c}100.0 \pm \\
4.5\end{array}$ & $\begin{array}{c}68.7 \pm \\
5.6\end{array}$ & $\begin{array}{c}88.0 \pm \\
7.7\end{array}$ & $\begin{array}{c}51.2 \pm \\
2.9\end{array}$ & $\begin{array}{c}72.6 \pm \\
3.9\end{array}$ & $\begin{array}{c}96.7 \pm \\
1.8\end{array}$ \\
\hline 0.025 & 0.002 & 0.007 & $\begin{array}{c}97.3 \pm \\
9.7\end{array}$ & $\begin{array}{c}88.3 \pm \\
2.2 \\
\end{array}$ & $\begin{array}{c}100.0 \pm \\
2.9\end{array}$ & $\begin{array}{c}73.9 \pm \\
4.8 \\
\end{array}$ & $\begin{array}{c}95.1 \pm \\
10.0 \\
\end{array}$ & $\begin{array}{c}66.5 \pm \\
4.8 \\
\end{array}$ & $\begin{array}{c}85.0 \pm \\
1.6 \\
\end{array}$ & $\begin{array}{c}96.4 \pm \\
2.1 \\
\end{array}$ \\
\hline
\end{tabular}

Note: * - the concentration of MF was determined by the content of magnetite, $* *$ - in comparison with the cells of the control group, which were cultured without adding the substances indicated in Table $3(100 \%)$, *** - it is not determined, or it is not determined reliably 
It has been shown by analysis of the data that HER2 antibody at concentrations less than 0.1 $\mu \mathrm{g} / \mathrm{mL}$ and PS in monoapplication do not affect significantly the viability or proliferation of MDA-MB-231 BC cells. Therefore, the $\mathrm{IC}_{50}$ is not determined for these ingredients, at the studied concentrations.

The $\mathrm{IC}_{50}$ was determined experimentally for gemcitabine to be $C_{\mathrm{GEM}}=0.016 \mathrm{mg} / \mathrm{mL}$, and for GEM/HER2 composition $\left(C_{\mathrm{GEM}}=0.016 \mathrm{mg} / \mathrm{mL}\right.$, $\left.C_{\text {HER2 }}=0.05 \mu \mathrm{g} / \mathrm{mL}\right)$ with respect to MDA-MB$231 \mathrm{BC}$ cells.

In the experiment, the $\mathrm{IC}_{50}$ value was not determined for MF at concentrations less than $0.1 \mathrm{mg} / \mathrm{mL}$ in the absence of toxicity. Cultivating MDA-MB-231 cells in the presence of MF and HER2 AB, simultaneously, we observed a slight synergistic effect of these components up to $4 \%$, compared with control 1.

Close to optimal concentrations of all components (MF, GEM and HER2 antibodies) were determined to achieve the highest cytotoxic effect of MF. Experimental studies have shown that the combination of concentrations of components $C_{\mathrm{MF}}=0.05 \mathrm{mg} / \mathrm{mL}, C_{\mathrm{GEM}}=0.004 \mathrm{mg} / \mathrm{mL}$, $C_{\text {HER } 2}=0.013 \mu \mathrm{g} / \mathrm{mL}$ creates the best result of cytotoxic activity, at which about $51.2 \%$ of MDA-MB-231 cells survive.

The results show that the proliferation of human breast carcinoma MDA-MB-231 cells is inhibited by GEM in individual use better than by other studied components. Under the conditions of complex action of GEM with other experimental substances, it has been found that:

- MF allows to increase the antitumor activity of GEM in vitro by $5.6-14.4 \%$;

- MF allows to increase the antitumor activity of HER2 antibody in vitro by $4.9-12.0 \%$,

- target-directed MF/GEM/HER2 complex causes a synergistic antitumor effect and increases the cytotoxic activity of GEM by more than $23 \%$.

This can be explained by the fact that in the mechanisms of realization of the apoptotic program under the influence of nanocomposite, a significant role is played by disorders of endogenous iron metabolism. Thus, when the nanocomposite system contains $\mathrm{Fe}_{3} \mathrm{O}_{4} / \mathrm{GEM} / \mathrm{HER} 2$ complexes, in human breast carcinoma MDA-MB-231 cells a significant increase is observed in the level of "free iron", which favours formation of reactive oxygen species and causes oxidative stress (Fenton reaction). The consequence of oxidative stress is the induction of apoptosis and enhancement of lipid peroxidation processes. It is proved that the nanocomposite is capable to initiate the apoptotic program in cells by mitochondrial pathway and cause structural and functional rearrangements of biological membranes [37].

\section{CONCLUSIONS}

Magnetic fluids were synthesized based on $\mathrm{Fe}_{3} \mathrm{O}_{4}$ and physiological solution, stabilized with sodium oleate and polyethylene glycol, containing GEM and HER2 antibody $\left(\mathrm{Fe}_{3} \mathrm{O}_{4} @\right.$ GEM/O1.Na/PEG/HER2+PS). The cytotoxic/cytostatic activity of MF was studied against MDA-MB-231 aggressive tumor cells of triple-negative human breast cancer with high proliferative and metastatic activity. It was found that as a result of application of synthesized MF composed of $\mathrm{Fe}_{3} \mathrm{O}_{4} @$ GEM/Ol.Na/PEG/HER2+PS at the concentration of magnetite of $0.05 \mathrm{mg} / \mathrm{mL}$, GEM - $0.004 \mathrm{mg} / \mathrm{mL}$ and HER2 AB $0.013 \mu \mathrm{g} / \mathrm{mL}$, a synergistic effect arose, with reduction of the amount of viable $\mathrm{BC}$ cells to $51 \%$.

It has been proved that when using MF based on targeted $\mathrm{Fe}_{3} \mathrm{O}_{4} /$ GEM/HER2 complex, the increased antitumor efficacy is observed compared to traditional use of the drug GEM, with a significant reduction (by four times) of its dose. The prospects have been shown of further studies of $\mathrm{Fe}_{3} \mathrm{O}_{4} @$ GEM/Ol.Na/PEG/HER2+PS MF in order to create on their basis a magnetically carried remedy for use in targeted antitumor therapy. 


\title{
Магніточутливі нанокомпозити для адресної протипухлинної терапії 3 використанням гемцитабіну
}

\author{
Н.М. Корнійчук, С.П. Туранська, А.Л. Петрановська, М.В. Абрамов, П.П. Горбик, Н.Ю. Лук'янова, \\ Н.В. Кусяк, В.Ф. Чехун
}

Інститут хімії поверхні ім. О.О. Чуйка Національної академії наук Украӥни вул. Генерала Наумова, 17, Київ,03164, Україна, phorbyk@ukr.net

Національний технічний університет Украӥни «Київський політехнічний інститут імені Ігоря Сікорського» просп. Перемоги, 37, Київ, 03056, Україна

Інститут експериментальної патологї, онкологї і радіобіології ім. Р.С. Кавецького Національної академії наук України вул. Васильківська, 45, Київ, 03022, Україна

Житомирський державний університет імені Івана Франка

вул. В. Бердичівська, 40, Житомир, 10008, Україна

Метою роботи є синтез $i$ дослідження властивостей поліфункиіональних магніточутливих нанокомпозитів (НК) та мішень-спрямованих магнітних рідин (МР) на основі фізіологічного розчину (ФР), магнетиту, гемщитабіну (ГЦ) та антитіла (АT) HER2, перспективних для використання в адресній протипухлинній терапї проти клітин лінії $M D A-M B-231$ агресивної пухлини з високою проліферативною та метастатичною активністю тричі негативного раку молочної залози (РМЗ) людини.

Питому поверхню $\left(S_{\text {пит }}\right)$ зразків визначали методом термодесорбиії азоту за допомогою приладу KELVIN 1042 фірми “COSTECH Instruments”. Розмір наночастинок (НЧ) очінювали за формулою $D_{B E T}=6 /\left(\rho S_{B E T}\right)$, де $\rho$ - густина частинки HK, $S_{B E T}-$ значення питомої площі поверхні, розрахованої за теорією полімолекулярної адсорбиї Брунауера, Еммета i Теллера (БЕТ). Дослідження стану поверхні нанодисперсних зразків здійснювали методами ІЧ-спектроскопї (Фур'є-спектрометр “Perkin Elmer”, модель 1720Х). Для розрахунку конщентрації гідроксильних груп на поверхні наноструктур використовували метод диференціального термічного аналізу в поєднанні з диференціальним термогравіметричним аналізом. Реєстрацію термограм здійснювали за допомогою дериватографа Q-1500D фірми МОМ (Угорщина) в інтервалі температур 20-1000 ${ }^{\circ} \mathrm{C}$ за швидкості нагрівання 10 град/хв. Рентгенофазовий аналіз наноструктур виконували за допомогою дифрактометра ДРОН-4-07 (випромінювання СиК 3 нікелевим фільтром у відбитому пучку, фокусування за Бреггом-Брентано). Розмір та форму НЧ визначали методом електронної мікроскопії (просвічуючий електронний мікроскоп (ПЕМ) JEM-2100F (Японія)). Петлі гістерезису магнітного моменту зразків вимірювали за допомогою лабораторного вібраційного магнітометра фонерівського типу при кімнатній температурі. Вимірювання оптичної густини, спектрів поглинання та концентрації ГЦ в розчинах здійснено методами спектрофотометричного аналізу (Spectrometer Lambda 35 UV/Vis Perkin Elmer Instruments). Кількість адсорбованої речовини на поверхні магнетиту визначали за допомогою спектрофотометра при $\lambda=268$ нм за калібрувальним графіком. Товщину адсорбованого шару ГЦ у складі $\mathrm{HK} \mathrm{Fe}_{3} \mathrm{O}_{4} @ \Gamma Ц$ визначали методом магнітної гранулометрії. Для вивчення прямої ичитотоксичної/циитостатичної дї̈ серії експериментальних зразків МР на основі ФР, НЧ $\mathrm{Fe}_{3} \mathrm{O}_{4}$, ГЦ, $\mathrm{AT} \mathrm{HER2}$, а також компонентів MP в моно- або комплексному застосуванні, на клітини лініі $M D A-M B-231$ in vitro, визначали показник $I C_{50}$.

Синтезовано МР на основі однодоменного $\mathrm{Fe}_{3} \mathrm{O}_{4}$ i ФР, стабілізовані олеатом натрію (Ол.Na) $i$

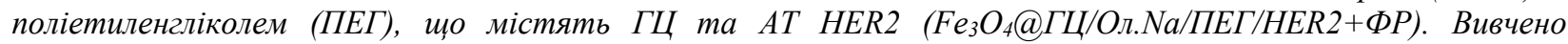
цุитотоксичну/цитостатичну активність МP щзодо клітин лінії $M D A-M B-231$. Встановлено, щзо

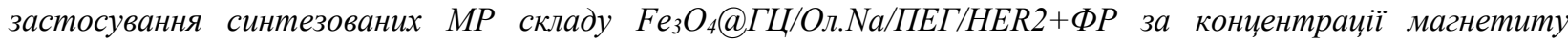
0.05 мг/мл, ГЦ - 0.004 мг/мл та АТ HER2 - 0.013 мкг/мл виявляло синергічний ефект та зменшувало кількість життєздатних клітин РМЗ до 51\%. Доведено, щзо використання МР на основі міменьспрямованого комплекса $\mathrm{Fe}_{3} \mathrm{O}_{4} /$ Г//НЕR2 характеризується підвищеною ефективністю протипухлинної дї̈, порівняно з традиційним застосуванням препарату ГЦ, при істотному зменшенні (у чотири рази) його дози. Високу цุитотоксичну/ц̧итостатичну активність комплексів $\mathrm{Fe}_{3} \mathrm{O}_{4} / \Gamma Ц / \mathrm{HER2}$ пояснено тим, щзо в механізмах реалізації апоптичної програми за впливу нанокомпозиту суттєву роль відіграють порушення обміну ендогенного заліза. Так, за наявністю в нанокомпозитній системі комплексів $\mathrm{Fe}_{3} \mathrm{O}_{4} / \Gamma Ц / \mathrm{HER2}$ у клітинах MDA-MB-231 спостерігається значне підвищення рівня «вільного заліза», що сприяє утворенню активних форм кисню та спричиняє оксидативний стрес (реакція Фентона). Наслідками оксидативного стресу $є$ індукиія апоптозу, посилення процесів перекисного окиснення ліпідів та структурно-функціональна перебудова біологічних мембран. Показано перспективність подальших досліджень МР 
$\mathrm{Fe}_{3} \mathrm{O}_{4} @$ $Г$ ЦОл.Na/ПЕГ/HЕR2+ФР 3 метою створення на їхній основі магнітокерованого лікарського засобу для використання в адресній протипухлинній терапї.

Ключові слова: гемцитабін, нанорозмірний однодоменний магнетит, нанокомпозити ядро-оболонка, магнітні рідини, антитіло HER2, адресна протипухлинна терапія

\title{
Магниточувствительные нанокомпозиты для адресной противоопухолевой терапии с использованием гемцитабина
}

\author{
Н.М. Корнийчук, С.П. Туранская, А.Л. Петрановская, Н.В. Абрамов, П.П. Горбик, Н.Ю. Лукьянова, \\ Н.В. Кусяк, В.Ф. Чехун
}

Институт химии поверхности им. А.А. Чуйко Наџиональной академии наук Украинь ул. Генерала Наумова, 17, Киев, 03164, Украина, phorbyk@ukr.net

Национальный технический университет Украины «Киевский политехнический институт имени Игоря Сикорского» просп. Победы, 37, Киев, 03056, Украина

Институт экспериментальной патологии, онкологии и радиобиологии им. Р.Е. Кавецєкого

Национальной академии наук Украинь

ул. Васильковская, 45, Киев, 03022, Украина

Житомирский государственный университет имени Ивана Франко

ул. Б. Бердичевская, 40, Житомир, 10008, Украина

\begin{abstract}
Цель работь - синтез и исследование свойств полифункииональных магниточувствительных нанокомпозитов (НК) и митень-направленных магнитных жидкостей (МЖ) на основе физиологического раствора (ФР), магнетита, гемцитабина (ГЦ) и антитела (АТ) HER2, перспективных для использования 6 адресной терапии трижды негативного рака молочной железы (РМЖ) человека - агрессивной опухоли с высокой пролиферативной и метастатической активностью (клетки линии МDA-MB-231).

Удельную поверхность $\left(S_{\text {уд})}\right.$ образиов определяли методом термодесорбичи азота с помощьью прибора KELVIN 1042 фирмы «COSTECH Instruments». Размер наночастиц (НЧ) оченивали по формуле $D_{B E T}=6 /\left(\rho S_{B E T}\right)$, где $\rho$ - плотность частищь $H K, S_{B E T}$ - значение удельной площади поверхности, рассчитанной по теории полимолекулярной адсорбции Брунауэра, Эммета и Теллера (БЭТ). Исследование состояния поверхности нанодисперсных образиов осуществляли методами ИК-спектроскопии (Фурьеспектрометр «Perkin Elmer», модель 1720X). Для расчета концентрации гидроксильньх групп на поверхности наноструктур использовали метод дифференциального термического анализа в сочетании с дифференциильным термогравиметрическим анализом. Регистрацию термограмм осуществляли с помощью дериватографа Q-1500D фирмы мОМ (Венгрия) в интервале температур 20-1000 ${ }^{\circ} \mathrm{Cpи}$ скорости нагрева 10 град/мин. Рентгенофазовый анализ наноструктур выполняли с помощью дифрактометра ДРОН-4-07 (излучение Сика с никелевым фильтром в отраженном пучке, фокусировка по Брэггу-Брентано). Размер и форму НЧ определяли методом электронной микроскопии (просвечиваюший электронный микроскоп (ПЭМ) JЕМ-2100F (Япония)). Петли гистерезиса магнитного момента образиов измеряли с помощью лабораторного вибрационного магнитометра фонеровского типа при комнатной температуре. Измерение оптической плотности, спектров поглощения и концентрации ГЦ в растворах осуществлено методами спектрофотометрического анализа (Spectrometer Lambda 35 UV/Vis Perkin Elmer Instruments). Количество адсорбированного вещества на поверхности магнетита определяли с помощьюю спектрофотометра при $\lambda=268$ нм по калибровочному графику. Толщину адсорбированного слоя ГЦ в составе $\mathrm{HK} \mathrm{Fe}_{3} \mathrm{O}_{4} @ \Gamma Ц$ определяли методом магнитной гранулометрии. Для изучения прямого изитотоксического/и̧итостатического действия серии экспериментальньх образиов МЖ на основе ФР, НЧ $\mathrm{Fe}_{3} \mathrm{O}_{4}, \Gamma Ц, \mathrm{HK} \mathrm{Fe}_{3} \mathrm{O}_{4} @ \Gamma Ц$, АT HER2, а также компонентов МЖ в моно- или комплексном применении, на клетки линии $M D A-M B-231$ in vitro, определяли показатель $I C_{50}$.

Синтезированы МЖ на основе $\mathrm{Fe}_{3} \mathrm{O}_{4}$ и ФР, стабилизированные олеатом натрия (Ол.Na) $u$

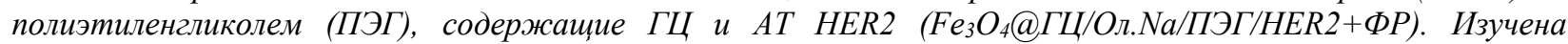
цุитотоксическая/ц̧итостатическая активность МЖ по отночению к клеткам линии MDA-MB-231.

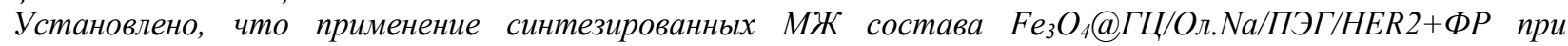
концентрации магнетита 0.05 мг/мл, ГЦ - 0.004 мг/мл и AT HER2 - 0.013 мкг/мл приводило к синергическому эффекту и уменьшению количества жизнеспособных клеток РМЖ до $51 \%$. Доказано, что
\end{abstract}


использование МЖ на основе мишень-направленного комплекса $\mathrm{Fe}_{3} \mathrm{O}_{4} / Г Ц / Н Е R 2$ характеризуется повышением эффективности противоопухолевого действия, по сравнению с традиционным применением препарата ГЦ, при существенном уменьшении (в четыре раза) его дозы. Высокая цุитотоксическая/цุитостатическая активность комплексов $\mathrm{Fe}_{3} \mathrm{O}_{4} /$ ГЦ/НЕR2 объяснена тем, что 6 механизмах реализации программы апоптоза при воздействии нанокомпозита существенную роль играют нарушения обмена эндогенного железа. Так, при наличии в нанокомпозитной системе комплексов $\mathrm{Fe}_{3} \mathrm{O}_{4} / Г Ц / H E R 2$ в клетках MDA-MB-231 наблюдается значительное повышение уровня «свободного железа», что способствует образованию активных форм кислорода и вызывает оксидативный стресс (реакиия Фентона). Последствиями оксидативного стресса являются индукция апоптоза, усиление процессов пероксидного окисления липидов и структурно-функииональная перестройка биологических мембран.

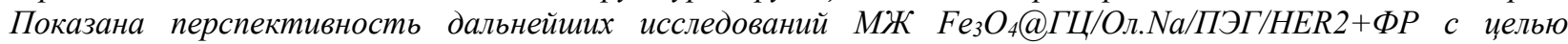
создания на их основе магнитоуправляемого лекарственного средства для использования в адресной противоопухолевой терапии.

Ключевые слова: гемичтабин, наноразмерный однодоменный магнетит, нанокомпозиты ядрооболочка, магнитные жидкости, антитело HER2, адресная противоопухолевая терапия

\section{REFERENCES}

1. Plentz R.R., Malek N.P. Systemic therapy of cholangiocarcinoma. Visc. Med. 2016. 32(6): 427.

2. Jain A., Kwong L.N., Javle M. Genomic profiling of biliary tract cancers and implications for clinical practice. Curr. Treat. Options Oncol. 2016. 17(11): 58.

3. Internet resource. Gemcitabine. Recent clinical trials of II and III stages in metastatic pancreatic cancer. 2017. [in Russian]. https://www.meir-health.ru

4. Gutorov S.L. Gemcitabine and pemetrexed: recent results in chemotherapy of solid tumors. Farmateka. 2005. 21: 16. [in Russian].

5. Arias J.L., Reddy L.H., Couvreur P. $\mathrm{Fe}_{3} \mathrm{O}_{4} /$ chitosan nanocomposite for magnetic drug targeting to cancer. J. Mater. Chem. 2012. 22(15): 7622.

6. Popescu R.C., Andronescu E., Vasile B.S., Truscă R., Boldeiu A., Mogoantă L., Mogosanu G.D., Temelie M., Radu M., Grumezescu A.M., Savu D. Fabrication and cytotoxicity of gemcitabine-functionalized magnetite nanoparticles. Molecules. 2017. 22(7): 1080.

7. Iglesias G.R., Reyes-Ortega F., Checa Fernandez B.L., Delgado Á.V. Hyperthermia-triggered gemcitabine release from polymer-coated magnetite nanoparticles. Polymers. 2018. 10(3): 269.

8. Petranovska A.L., Abramov M.V., Opanashchuk N.M., Turanska S.P., Kusyak N.V., Gorbyk P.P. Synthesis and properties of magnetically sensitive nanocomposites based on magnetite and gemcitabine. Him. Fiz. Tehnol. Poverhni. 2018. 9(4): 353.

9. Petranovska A.L., Abramov M.V., Opanashchuk N.M., Turanska S.P., Gorbyk P.P., Kusyak N.V., Kusyak A.P., Lukyanova N.Yu., Chekhun V.F. Magnetically sensitive nanocomposites and magnetic liquids based on magnetite, gemcitabine, and antibody Her2. Him. Fiz. Tehnol. Poverhni. 2019. 10(4): 419.

10. Gorbyk P.P. Medico-biological nanocomposites with nanorobot functions: state of investigations, development, and prospects of practical introduction. Him. Fiz. Tehnol. Poverhni. 2020. 11(1): 128. [in Ukrainian].

11. Abramov M.V., Petranovska A.L., Kusyak N.V., Kusyak A.P., Opanashchuk N.M., Turanska S.P., Gorbyk P.P., Luk'yanova N.Yu., Chekhun V.F. Synthesis and properties of magnetosensitive nanocomposites and ferrofluids based on magnetite, gemcitabine and HER2 antibody. Funct. Mater. 2020. $27(2): 1$.

12. Levy L., Sahoo Y., Earl B.J. Synthesis and characterization of multifunctional nanoclinics for biological applications. Chem. Mater. 2002. 14: 3715.

13. Shpak A.P., Gorbyk P.P. Nanomaterials and Supramolecular Structures: Physics, Chemistry, and Applications. (Nederlands: Springer, 2009).

14. Gorbyk P.P., Turov V.V. Nanomaterials and Nanocomposites in Medicine, Biology, Ecology. (Kyiv: Naukova Dumka, 2011). [in Russian].

15. Patent UA 99211. Gorbyk P.P., Petranovska A.L., Turelyk M.P., Turanska S.P., Vasylieva O.A., Chekhun V.F., Luk’yanova N.Yu., Shpak A.P., Korduban O.M. Nanocapsule with nanorobot functions. 2012.

16. Gorbyk P.P., Chekhun V.F. Nanocomposites of medicobiologic destination: reality and perspectives for oncology. Funct. Mater. 2012. 19(2): 145. 
17. Gorbyk P.P. Nanocomposites with functions of medico-biological nanorobots: synthesis, properties, application. Nanosystems, Nanomaterials, Nanotechnologies. 2013. 11(2): 323. [in Ukrainian].

18. Gorbyk P.P., Lerman L.B., Petranovska A.L., Turanska S.P. Magnetosensitive Nanocomposites with Functions of Medico-Biological Nanorobots: Synthesis and Properties. In: Advances in Semiconductor Research: Physics of Nanosystems, Spintronics and Technological Applications. (NY: Nova Science Publishers, 2014).

19. Gorbyk P.P., Lerman L.B., Petranovska A.L., Turanska S.P., Pylypchuk I.V. Magnetosensitive Nanocomposites with Hierarchical Nanoarchitecture as Biomedical Nanorobots: Synthesis, Properties, and Application. In: Fabrication and Self-Assembly of Nanobiomaterials, Applications of Nanobiomaterials. (Elsevier, 2016).

20. Pylypchuk I.V., Abramov M.V., Petranovska A.L., Turanska S.P., Budnyak T.M., Kusyak N.V., Gorbyk P.P. Multifunctional magnetic nanocomposites on the base of magnetite and hydroxyapatite for oncology applications. In: Nanochemistry, Biotechnology, Nanomaterials, and Their Applications (NANO 2017). Selected Proc. 5th Int. Conf. "Nanotechnology and Nanomaterials" (Aug. 23-26, 2017, Chernivtsi, Ukraine). P. 35.

21. Abramov M.V., Kusyak A.P., Kaminskiy O.M., Turanska S.P., Petranovska A.L., Kusyak N.V., Gorbyk P.P. Magnetosensitive Nanocomposites Based on Cisplatin and Doxorubicin for Application in Oncology. In: Horizons in World Physics. (Nova Publishers, 2017). 293: 1.

22. Uvarova I.V., Gorbyk P.P., Gorobets' S.V., Ivashchenko O.A., Ulianchenko N.V. Nanomaterials of Medical Destination. (Kyiv: Naukova Dumka, 2014). [in Ukrainian].

23. Gorobets' S.V., Gorobets' O.Yu., Gorbyk P.P., Uvarova I.V. Functional Bio- and Nanomaterials of Medical Destination. (Kyiv: Kondor, 2018). [in Ukrainian].

24. Kusyak A.P., Petranovska A.L., Gorbyk P.P. Adsorption of $\mathrm{Pb}^{2+}$ cations from blood plasma by nanocomposites based on magnetite. Surface. 2016. 8(23): 179. [in Ukrainian].

25. Abramov M.V., Turanska S.P., Gorbyk P.P. Magnetic properties of nanocomposites of superparamagnetic coreshell type. Metalofizyka i Novitni Tekhnologiyi. 2018. 40(4): 423. [in Ukrainian].

26. Abramov M.V., Turanska S.P., Gorbyk P.P. Magnetic properties of fluids based on polyfunctional nanocomposites of superparamagnetic core-multilevel shell type. Metalofizyka i Novitni Tekhnologiyi. 2018. 40(10): 1283. [in Ukrainian].

27. Karaman O.M., Fedosova N.I., Voyeikova I.M., Cheremshenko N.L., Ivanchenko A.V., Savtsova Z.D. Prospects of application of lectins for diagnostics and treatment of malignant neoplasms. Onkologiya. 2018. 20(1): 10. [in Ukrainian].

28. Turanska S.P., Opanashchuk N.M., Petranovska A.L., Kusyak N.V., Tarasiuk B.I., Gorobets' S.V., Turov V.V., Gorbyk P.P., Abramov M.V. Synthesis, properties of nanocomposites based on gemcitabine, and application in oncotherapy. Poverkhnia'. 2019. 11(26): 577. [in Ukrainian].

29. Moiseenko V.M. Probabilities of monoclonal antibodies in treatment of malignant tumors. Practical Oncology. 2002. 3(4): 253. [in Russian].

30. Tan M., Yu D. Molecular mechanisms of erbB2-mediated breast cancer chemoresistance. Adv. Exp. Med. Biol. 2007. 608: 119 .

31. Santin A.D., Bellone S., Roman J.J., McKenney J.K., Pecorelli S. Trastuzumab treatment in patients with advanced or recurrent endometrial carcinoma overexpressing HER2/neu. Int. J. Gynaecol. Obstet. 2008. 102(2): 128.

32. Borisenko N.V., Bogatyrev V.M., Dubrovin I.V., Abramov N.V., Gayevaya M.V., Gorbyk P.P. Synthesis and Properties of Magnetosensitive Nanocomposites Based on Oxides of Iron and Silicon. In: Physics and Chemistry of Nanomaterials and Supramolecular Structures. (Kyiv: Naukova Dumka, 2007). 1: 394. [in Russian].

33. Mornet S., Vasseur S., Grasset F., Veverka P., Goglio G., Demourgues A., Portier J., Pollert E., Duguet E. Magnetic nanoparticle design for medical applications. Prog. Solid State Chem. 2006. 34(2-4): 237.

34. Petranovska A.L., Abramov N.V., Turanska S.P., Gorbyk P.P., Kaminskiy A.N., Kusyak N.V. Adsorption of cis-dichlorodiammineplatinum by nanostructures based on single-domain magnetite. J. Nanostruct. Chem. 2015. 5: 275.

35. Abramov N.V., Turanska S.P., Kusyak A.P., Petranovska A.L., Gorbyk P.P. Synthesis and properties of magnetite/hydroxyapatite/doxorubicin nanocomposites and magnetic fluids based on them. J. Nanostruct. Chem. 2016. 6: 223.

36. Freshni R.Ya. Animal Cell Culture: Practical Manual. (Moscow: BINOM, Laboratoriya znania, 2010). [in Russian].

37. Luk'yanova N.Yu. Doctoral (Biol.) Thesis. (Kyiv, 2015). [in Ukrainian]. 